\title{
Do comissariado de Deus à vontade do 'princeps': lei, autoridade e soberania no pensamento político medieval tardio
}

Raquel Kritsch ${ }^{1}$

Universidade Estadual de Londrina

kritsch@uel.br

resumo 0s problemas da lei e da autoridade marcaram fortemente o pensamento político medieval ocidental, e em especial o desenvolvimento da noção de soberania, ponto de convergência dos grandes conflitos de jurisdição no período. 0 debate acerca da distribuição das jurisdições constituiu um dos momentos importantes para a construção da moderna idéia de soberania. Na medida em que se tomava a lei como dada, o sentido da autoridade tinha necessariamente de ser vinculado à idéia de comissão: a autoridade era um atributo daquele que podia fazer cumprir a lei em nome do legislador divino. Outro momento relevante foi o da emergência do problema do poder legislativo, tal como entendido modernamente. Jurisdição, a partir daí, passaria a incluir também o direito de criar e de impor as normas válidas para toda a comunidade por um legislador agora humano. Aos poucos, a vontade do príncipe, que não se limita mais pelo rigor da razão e da moralidade, passa a ser entendida como fonte criadora, transformadora e revogadora da lei. Mostrar as linhas gerais deste percurso constitui o objetivo imediato deste artigo.

palavras-chave Estado; soberania; direito; história do pensamento político; teoria política medieval

Não há grande discordância, entre os historiadores do pensamento político medieval, de que a noção de justiça constituía um dos grandes temas de relevo do período, sobretudo em sua primeira fase, a chamada baixa idade média. Pode-se notar até mesmo um consenso em relação à idéia de que a primeira e principal tarefa da comunidade política era a manutenção da justiça, como se pode ler em autores tão distintos quanto E. Cassirer 
(CASSIRER, 1976, p. 114), C. Friedrich (FRIEDRICH, 1969, pp. 7980) ou F. Calasso (CALASSO, 1965, p. 260).

A noção de que a justiça era o fundamento de todo o direito e da sociedade organizada remonta, no mínimo, a Cícero e foi reafirmada por Santo Agostinho quando escrevia que onde não existisse justiça não existiria sociedade, não haveria verdadeira res publica Assim, a finalidade e a razão de ser do poder político na idade média consistia em implantar o reino da justiça na terra; e era diante de Deus que o soberano respondia pelo cumprimento desse seu dever primordial. Sobre esse ponto não havia dúvidas. As divergências só apareciam quando se tratava de definir o fundamento e a amplitude da intervenção da igreja, representante de Deus na terra (CHEVALIER, 1982, p. 206).

Contudo, vale lembrar que na idade média não se podia conceber a idéia de uma justiça abstrata e impessoal: a lei ou o direito - a forma concreta e definida da justiça - tinha de ter uma fonte pessoal. Sem um legislador não podia existir lei. E, se a justiça não devia ser considerada algo acidental nem simples matéria de convenção, esse legislador tinha de estar acima de todas as forças humanas: ele constituía uma vontade sobrehumana que se manifestava na justiça, fosse ela divina ou natural.

Além dessa noção de justiça como fundamento do ordenamento social, a influência estóica sobre o pensamento medieval manifestava-se ainda em outros aspectos relevantes, como a máxima da igualdade fundamental entre os homens - noção que se tornaria um dos pontos centrais da teoria política medieval: "Era um axioma geral da Teologia e Jurisprudência medievais que, de acordo com a 'natureza' e na ordem original das coisas, todos os homens eram livres e iguais" (CASSIRER, 1976, p. 121). E eram considerados iguais porque dotados, todos, da mesma faculdade da razão que, para os teólogos, constituía a imago Dei. Assim, cada alma era declarada sui iuris; não podia, portanto, renunciar à sua liberdade original.

Seguia-se daí que nenhum poder político podia ser absoluto: estaria sempre limitado pelas leis da justiça, que eram consideradas irrevogáveis e invioláveis porque exprimiam a própria ordem divina, a vontade do supremo legislador. Todos os príncipes estavam subordinados a ela, tal como ilustrava a conhecida fórmula medieval da lex facit regem ${ }^{2}$. Bobbio recorda que o princípio de legalidade era bastante antigo: ligava-se ao 
ideal grego de isonomia (igualdade de todos diante das leis), considerada a essência do bom governo.

Este princípio de legalidade, segundo ele, pode ser distinguido de pelo menos três modos, considerando-se a relação entre a lei, entendida como norma geral e abstrata, e o poder: 1) o príncipe tinha de governar de acordo com leis superiores a ele (fossem elas positivas, divinas ou naturais) e, portanto, não era legibus solutus; 2) os governantes só deviam promulgar leis válidas para todos; só excepcionalmente poderia ele governar por meio de decretos e ordenações; 3) julgamentos de casos particulares deviam ser feitos com base em prescrições definidas na forma de normas legislativas (BOBBIO, 1986, p. 675).

Pode-se afirmar sem muitas ressalvas, portanto, que ao longo do medievo europeu o poder do rei esteve limitado por uma dupla afirmação: a da supremacia da lei e a da supremacia da comunidade - idéia reforçada, na opinião de Chevalier, pela noção de um pacto existente entre o rei e a comunidade (oriunda das tribos germânicas), com a supremacia implícita da última ${ }^{3}$.

Seria apenas com a recuperação do direito romano, a partir dos séculos X-XI na Europa ocidental, que a figura do princeps legibus solutus isentar-se-ia de limitações legais, num lento e relutante desenvolvimento teórico que culminaria na conhecida figura das monarquias absolutas do século XVI, tal como teorizadas por Jean Bodin e imortalizadas no Leviatã de Thomas Hobbes. Um desenvolvimento cujas raízes históricas podem ser localizadas nas disputas de jurisdição entre os poderes temporal e espiritual que marcaram os séculos finais do medievo europeu.

Ora, se a questão da justiça pode ser considerada um dos grandes temas de boa parte da reflexão legal e política do medievo europeu, não é menos verdadeiro que as disputas em torno da definição da idéia de soberania tenham constituído, sem grande margem de dúvida, um dos assuntos mais importantes para a organização do pensamento político moderno. Pode-se afirmar que, em certo sentido, soberania funciona como um tema ordenador.

O pensamento político moderno, como é de domínio público, ocupou-se de questões como poder, autoridade, lei, direito, liberdade, polis, civitas, etc. No entanto, pode-se tomar uma única noção, a de soberania, como idéia organizadora, em relação à qual cada um destes temas 
pode ser nitidamente situado. Quando se fala em poder, no pensamento político ocidental moderno, por exemplo, somos remetidos necessariamente a pensar a presença do Estado. E não há como pensar a presença ou o significado desta formação política na tradição moderna sem recorrer ao tema da soberania ${ }^{4}$. O mesmo ocorre com as questões da lei e da fonte de sua positividade, com o contraste entre direito natural e positivo, e assim por diante. Mas não se trata de buscar na idade média conceitos que lá não se encontram - e isto é importante frisar. Trata-se apenas de indicar historicamente os pontos que, no desenrolar dos debates e lutas, viriam a apontar a formação deste conceito.

Assim, se o pensamento político moderno tem como centro de gravidade a noção de soberania, conceber o seu nascimento é necessariamente imaginar como se criaram as condições para a construção do conceito de soberania. Isto é, significa pensar não só o processo teórico por meio do qual esse conceito foi moldado mas também o percurso histórico-político pelo qual ele se construiu. Não se pode esquecer que a teoria política é parte da história política. Ou se imagina um corte radical na história, com um antes e um depois; ou, alternativamente, deve-se imaginar que, em algum momento da chamada idade moderna, tem-se o resultado do desenvolvimento de fatos e de conceitos que, sem passar por nenhuma data clara, se manifestam e se vão conformando no tempo ${ }^{5}$.

Esta concepção do estudo genético explica tanto os cuidados quanto aparentes licenças que poderão surgir no texto. $\mathrm{O}$ cuidado principal é não buscar, no processo formador, nem o Estado como o conhecemos a partir do século XVI, nem uma teoria da soberania tal como a sistematizada por Bodin ou por Hobbes. É inútil, neste caso, trabalhar com imagens prontas e tipos cristalizados e separados da história. Portanto, não se vai tomar, por exemplo, a definição weberiana de Estado e percorrer a história em busca do que se possa enquadrar no molde.

Também não se entrará numa pesquisa filológica. $\mathrm{O}$ objetivo não é examinar textos antigos em busca de palavras como stato e souverain e discutir seu sentido preciso. Tratar da gênese do Estado e da noção de soberania, isto é, da formação de uma ordem política e de sua representação ideológica e jurídica, envolve em primeiro lugar tarefas de outra natureza. O objeto "Estado" ou "Estado em formação" pode ser designado por muitos nomes (regnum, por exemplo). Da mesma forma, os atri- 
butos do poder soberano são indicáveis por muitas palavras diferentes do termo "soberania" (plenitudo potestatis, summa postestas, entre outras).

O mais importante é identificar claramente as pretensões e os valores em jogo nas disputas de poder. Uma descrição dos conflitos de maior conseqüência nos séculos XIII e XIV, na Europa, envolveria no mínimo os seguintes elementos: 1) as pretensões de domínio temporal do papa, do imperador e dos reis; 2) a superposição ou separação das normas eclesiásticas e seculares; 3) a hierarquização das normas temporais (por exemplo: a relação entre direito costumeiro regional e normas gerais ditadas por outras esferas de poder); 4) a divisão das funções judiciárias.

Todas essas questões podem ser entendidas como disputas de jurisdição. Trata-se de saber quem julga e quem pune delitos civis ou violações de normas religiosas, o que já implica a distinção entre duas ordens normativas e duas classes de autoridade. Trata-se de estabelecer a extensão de poderes, como, por exemplo, o de tributar. O frade é subordinado apenas ao papa ou é também súdito do rei e, portanto, pessoa tributável? Ou de esclarecer em nome de quê, ou de quem, se julga esta ou aquela causa judicial e a que instância cabe a sentença definitiva. Estes problemas conduziram, nos séculos XIII e XIV, a uma posição mais clara do tema da jurisdição territorial.

O tema da distribuição das jurisdições, isto é, de quem faz cumprir as leis em nome do Deus legislador, constituiu um dos momentos importantes para a construção da moderna idéia de soberania. A disputa em torno das investiduras, por exemplo, ocorrida no século XI, envolveu tanto a questão do domínio territorial quanto a divisão da autoridade entre as esferas temporal e espiritual - uma "demarcação de atribuições" que punha em xeque o modelo cesaropapista de Bizâncio, até então uma referência de peso para a cristandade ocidental e seus governantes.

O outro momento relevante que marcaria o avanço da noção de soberania na direção da formulação que seria consagrada pela modernidade política foi o da emergência do problema do poder legislativo, tal como entendido modernamente. Jurisdição, a partir daí, passaria a incluir também o direito de criar e de impor as normas válidas para toda a comunidade por um legislador agora humano, que seria ser localizado sobretudo na figura do príncipe (Hobbes) ou na da comunidade (Rousseau). Mostrar as linhas gerais deste desenvolvimento constitui assim o objetivo imediato deste artigo. 
Os poderes de legislar, de mudar a lei, de resolver como última instância e de controlar o uso da violência constituem o que os autores modernos nomearam soberania. Se todos aqueles conflitos de jurisdição ocorressem de forma desarticulada, seria abusivo vinculá-los à formação da idéia de poder soberano. Mas também não se poderia tratá-los como aspectos da constituição do Estado. Ou, dito de outra forma: as grandes unidades políticas européias, bem desenvolvidas no século XVI, teriam de ser vistas como resultantes de uma série de atos desconexos. Uma coisa é reconhecer processos que ultrapassam a intenção dos atores. Outra é negligenciar, ou desvalorizar, a articulação dos comportamentos intencionais.

Parece mais razoável a combinação de duas perspectivas: nem fazer da história o produto de um plano, nem reduzi-la a retalhos inteiramente desligados das intenções dos atores. Os reis, os papas e os imperadores, indubitavelmente, não tinham desenhada na mente, com todos os traços, a imagem do mundo que estavam construindo. Mas tinham, certamente, uma visão organizada de suas ambições e dos objetos em disputa. Quando Felipe, o Belo, rei de França, se opôs ao papa Bonifácio VIII por uma questão tributária, o que se discutia era, nitidamente, o seu direito de cobrar impostos num dado território, com base numa lei de seu reino, com uso de sua força e com a exclusão de qualquer outra autoridade. Aceitos estes pontos, falar em Estado (como objeto em formação) e em soberania (ponto de convergência dos grandes conflitos de jurisdição) deixa de ser um anacronismo. Poderá soar como licença, ocasionalmente; porém, autorizada por toda a argumentação apresentada até aquí.

Pode-se depreender, portanto, de tudo o que foi afirmado acima que as questões fortes que iriam marcar o pensamento político medieval ocidental, e que convergiriam para a questão da soberania, consistiam basicamente nas discussões em torno do problema da lei e da autoridade. Seria ao redor desses temas intimamente interligados que a questão da soberania iria se constituir como um tema de peso no pensamento político. Para se entender tal imbricação, talvez seja útil esclarecer o que se entendia por lei, de modo genérico, na idade média.

Uma das concepções medievais mais primordiais de lei foi aquela herdada das tribos germânicas. Nesta, a lei era considerada possessão própria e atributo distintivo do grupo, comunidade ou povo que ela 
governava. Era assim essencialmente costume (CHEVALIER, 1982, p. 207) e, como tal, relacionava-se às ditas leis humanas.

Carl Friedrich explica que por lei humana entendia-se no medievo tanto a lei escrita quanto a costumeira; dividia-se em direito romano, direito canônico, direito local do rei e direito consuetudinário. Isto é, as leis humanas escritas podiam ser, em diferentes momentos, a lei do império romano, o direito canônico - que de certa maneira participava da dupla natureza de lei humana e lei de origem divina - e até as leis dos reinos. Já a lei costumeira consistia fundamentalmente no direito local, regional, tradicional e assim por diante (FRIEDRICH, 1969, p. 71).

A autoridade da lei costumeira era perfeitamente conciliável com a herança dos antigos, a saber, a crença na realidade do direito natural, herdada da tradição estóica e transmitida aos medievais sobretudo por meio dos escritos de Cícero. Acima das normas humanas, elevavam-se a lei natural e a lei divina, às quais o governante cristão estava subordinado.

Assim, para o pensamento medieval ocidental, existiam príncipes, senhores, domínio e governo. Ao rei cabia a tarefa de fazer justiça e designar os castigos, por ser o juiz supremo, além de cuidar da guerra e das relações exteriores. Nada além. O direito medieval negava aos príncipes qualquer poder legislativo irrestrito: as noções de que toda lei era fundamentalmente um costume jurídico e de que a legislação só tinha por função aclarar e elucidar esta lei costumeira constituíam, deste modo, idéias básicas. Portanto, é apenas dentro da concepção de um governo primordialmente judicial que se pode compreender a filosofia jurídica e a lei natural do medievo (FRIEDRICH, 1969, pp. 69-70).

Numa primeira fase do pensamento medieval, os pensadores políticos fizeram uso basicamente das noções de lei divina e de lei natural, tomando a lei como um dado, já que provinham das Escrituras. Neste ponto, pode-se afirmar a existência de uma certa identidade entre o pensamento medieval cristão, o muçulmano e o judaico: em todos eles, os textos sagrados são tomados como fontes da lei. A lei natural, por sua vez, por constituir um dado do mundo físico, também consistiria numa norma posta, à qual se acedia pela razão ou pelo coração.

E aqui vale chamar atenção para um ponto relevante: a tendência predominante do pensamento político medieval era a de apresentar a lei natural como um reflexo da lei divina; isto é, a lei natural não seria menos 
produzida por Deus do que aquela das Escrituras: também ela era um produto de Deus. O que as diferenciava era simplesmente a forma de acesso, isto é, a forma de conhecimento de cada uma delas. Num caso, o da lei divina, o acesso se dava pela revelação; no outro, o da lei natural, pelas faculdades racionais dos homens. Mas, no fundo, a sua origem e os seus ditames eram os mesmos.

Vale lembrar ainda que tanto a noção de lei divina quanto a de lei natural apareciam já nos primórdios do pensamento cristão e podiam ser encontradas nos textos evangélicos, como em São Paulo, por exemplo, quando ele se refere ao fato de que certas normas deveriam ser seguidas também por aqueles que não conheciam a revelação (ROM., 1995, p. 1385) - na prática, uma forma de estender a responsabilidade moral também aos pagãos.

Até mesmo a norma costumeira, durante uma determinada fase, fora tomada, num certo sentido, como uma regra dada. Isto é, por ser costumeira, ela constituía um dado e devia ser respeitada também por aquele que exercia o poder político. Foi parte, no entanto, do processo de transformação do poder político e de seu significado o fato de que este poder se afirmasse de tal modo que a própria lei costumeira passasse a estar subordinada a esta autoridade. Quando a constituição da idéia de soberania já se encontrava bastante avançada, entraria na sua própria definição a noção de que constituiria uma atribuição do soberano validar a norma costumeira ${ }^{7}$, como afirma, por exemplo, Hobbes.

$\mathrm{Na}$ medida em que se tomava a lei como dada, o sentido da autoridade tinha necessariamente de ser vinculado à idéia de comissão. Isto é, a autoridade era um atributo daquele que podia fazer cumprir a lei, não em nome próprio, mas em nome do Legislador, que era Deus. Uma parte da disputa política na idade média entre os chamados poder temporal e o poder eclesiástico, não consistia em saber quem tinha o direito de legislar, mas em saber quem teria a autoridade para fazer cumprir uma lei que era dada.Tratava-se, neste caso, de uma disputa em torno da função de representação da vontade divina.

Entretanto, quando se passa a refletir sobre a lei humana e o sentido da autoridade nela contida, está-se diante de uma questão nova. A noção de autoridade, na sua relação com a lei, assume aqui dois significados diferentes, embora em meio às disputas políticas esses dois sentidos com 
freqüência tenham se sobreposto e se confundido. A rigor, no entanto, trata-se de dois sentidos distintos, que se vinculam às questões da forma de conhecimento da lei e da fonte legisladora.

Assim, pode-se tratar a questão da lei a partir de, pelo menos, duas perspectivas. A primeira é aquela da sua forma de conhecimento. Isto é, podiase conhecer a lei porque ela era dada: pela revelação nas Escrituras; pelo exercício da razão; pela manifestação do coração; pelo costume ou por um texto sagrado. Esta era uma perspectiva de tratamento da questão da lei.

A outra perspectiva era a da fonte legisladora, que inicialmente localizava-se em Deus, o encarregado de produzir tanto as normas da revelação quanto as normas naturais. Com os acréscimos oferecidos sobretudo pelos pensadores dos séculos XII e XIII, no entanto, a fonte legisladora passaria a ser cada vez mais associada à criatura humana, em duas formas básicas: a da comunidade e do soberano.

Boa parte do debate medieval consistiu na tentativa de determinar até que ponto as leis, alegadamente atribuídas a Deus, podiam de fato ser atribuídas a Ele; e, até que ponto, as normas deveriam ser atribuídas a instâncias humanas. Isto envolveu, entre outras coisas, uma discussão sobre o significado da autoridade naquele primeiro sentido mencionado: o de agir em nome de um Deus legislador.

Esta questão assumia duas formas diferentes: uma delas consistia em saber a quem Deus atribuiu de fato essas funções e até que ponto elas foram atribuídas à igreja e, especialmente, ao papa, ou ainda podiam ser desempenhadas pelo detentor do poder secular. A outra consistia em saber até que ponto a igreja ou o papa, ao falar em nome de Deus, estaria efetivamente transmitindo a lei divina; e até que ponto estaria transmitindo uma lei eclesiástica, que era de criação humana.

Neste debate em torno do alcance da lei humana, o significado da noção de autoridade iria ampliar-se. Passaria a indicar não só a atribuição de impor uma ordem, mas também a de construí-la. Porém, quando se considera a lei humana neste período, não se deve perder de vista o papel e a relevância das demais normatividades, pois a discussão a respeito da lei natural e da lei divina nunca seria inteiramente deixada de lado. Feita esta ressalva, porém, pode-se afirmar que a reflexão acerca do sentido da relação entre a autoridade e o direito codificado, e entre a autoridade e as normas costumeiras, passava a ser cada vez mais relevante. 
Como recorda Chevalier, “à proporção que se foi desenvolvendo a sociedade medieval e que as suas instituições políticas foram adquirindo maior complexidade, tornou-se necessário recorrer a uma concepção diferente: a da lei como expressão de uma vontade consciente, deliberada" (CHEVALIER, 1982, p. 207). A recuperação do direito romano sem dúvida contribuiu para intensificar o movimento das idéias nesse sentido. Seus importantes desdobramentos apareceriam com clareza nas disputas de jurisdição entre os poderes temporal e espiritual que marcaram, entre outros, a chamada Querela das Investiduras (1073-1122), cujos avanços deveu muito aos acréscimos teóricos dos juristas da igreja (canonistas) e do imperador (civilistas) ${ }^{8}$ formados nas universidades emergentes em toda Europa ao longo dos séculos XII e XIII, entre as quais se destacava a Universidade de Bolonha, principal centro da produção e da reflexão jurídicas do período.

O Decretum - uma coleção de documentos legais da igreja codificada por Graciano de Bolonha por volta de 1140, mais conhecida dos juristas pelo nome de ius novum, e que mais tarde passaria a integrar o Corpus Iuris Canonicii - foi uma das primeiras compilações comentadas sobre jurisprudência da alta idade média e representou um importante passo para esta discussão.

Graciano seguia Isidoro de Sevilha ao definir a lei natural como aquela lei comum a todas as nações - encontrada em todas as terras mais por causa do instinto natural imutável dos homens do que em razão de qualquer promulgação positiva9. Mas ele ia além, adaptando a lei natural ao preceito divino básico do amor ao semelhante: "A humanidade é regida por duas coisas: pela leis naturais e pelos costumes. Lei natural é aquela que está contida nas Escrituras, segundo a qual cada um é obrigado a fazer para outro como quer que seja feito para si mesmo, e proibido de fazer a outro o que não deseja que seja feito a si mesmo" (LUSCOMBE \& EVANS, 1991, p. 314).

O mestre Graciano prosseguia em sua definição, discutindo os tipos de leis humanas, que, para ele, podiam ser costumes não-escritos, a lei civil, a lei de uma cidade ou de um povo e os diferentes tipos de lei da tradição da lei romana; e terminava a explicação definindo a validade da lei: "As leis são estabelecidas por meio de promulgação e validadas quando são aprovadas pela aceitação do povo" (PENNINGTON, 1991, p. 424). Com estes acréscimos, Graciano integrava a doutrina clássica dos antigos à cristã. 
Mas como se pode pensar o problema do poder supremo diante da questão da lei no pensamento medieval? A pergunta certamente não comporta uma resposta única mas pode nos oferecer algumas pistas para entender o problema do desenvolvimento político, de modo geral.

Depois da redescoberta do Digesto, de Justiniano - uma das quatro partes do Codex Iustinianus, formado por cinqüenta livros com citações de juristas romanos, e que seria reunido, juntamente com o Codex Constitutionum, ao Corpus Iuris Civilis, compilado pelos legistas no medievo -, os juristas ocuparam-se em examinar a fonte da autoridade legislativa na sociedade e a relação entre o monarca e a velha lei. O problema era conciliar a autoridade legislativa do monarca, que agora substituía o imperador romano, com o poder do costume legal. Azzone, por exemplo, afirmava que o costume mantinha, fazia, ab-rogava e interpretava a lei. Muitos legistas sempre notaram que a produção de uma nova lei era função natural da sociedade. Havia contudo pontos de vista diferentes, como o dos civilistas, que definiam a lei como vontade do príncipe, promulgada por razões justas e necessárias e temperada pelo costume ${ }^{10}$.

A partir de meados do século XII, quando o Decretum de Graciano havia determinado às escolas o estudo da lei canônica, os estudantes puderam aperfeiçoar as definições dos juristas e criaram uma terminologia mais precisa. Embora a idéia do predomínio da norma (e da justiça) tenha permanecido como ideologia dominante no século XIII, a questão das relações entre o príncipe e a lei vinha sendo revista desde o século XII. No fim deste, os canonistas haviam forjado o termo ius positivum, ou lei positiva, para descrever a lei promulgada pelo legislador humano, o que permitiria avançar conceitualmente.

Pennington chama atenção para a dificuldade de interpretar a relação entre príncipe e lei a partir da tradição romana. Diferentes textos de Justiniano sustentavam afirmações distintas e, por vezes, contraditórias: no Digna vox (Codex I.14.4), ele escrevia que o imperador era a fonte de toda lei mas devia conduzir suas ações de acordo com a legalidade, como os governantes constitucionais; já no Digesto ele enfatizava a autoridade ilimitada do imperador e seu poder absoluto (PENNINGTON, 1991, p. 426). Estes textos, nas mãos dos peritos da lei, acabariam sendo usados para sustentar tanto sistemas monárquicos constitucionais quanto absolutos. 
Nas várias universidades, o desenvolvimento da jurisprudência e da reflexão jurídico-política respondia, com freqüência, a interesses opostos e, no entanto, com resultados convergentes. Alguns aspectos desse desenvolvimento podem surpreender. A formulação mais radical da idéia de poder absoluto pertence, provavelmente, aos canonistas. Acabou incorporada, no entanto, pelos mais severos defensores do poder secular, imperial ou do reino.

No início do século XIII, os legistas canonistas começaram a entender - contra as concepções germânica e antiga da lei, que fundiam o conteúdo da lei (que devia ser justo e razoável) com a fonte da lei - que a vontade do príncipe podia ser separada do conteúdo da lei. Neste sentido, eles foram os primeiros juristas da tradição ocidental a estabelecer a lei como um elemento essencial da teoria política.

A noção de que a vontade do soberano, e não a justiça, era o elemento essencial da lei, foi posta por um canonista do século XIII, Laurentius Hispanus - glosador decretista da igreja, especializado em comentários ao Decretum -, contra uma das mais firmes tradições da política medieval. Separando a vontade do príncipe do conteúdo da lei, Hispanus tornava a lei plenamente caracterizável sem referência à moralidade ou a qualquer conceito transcendente de justiça.

Com isso, ele não só situava a fonte da autoridade legislativa na vontade do príncipe mas ainda abria caminho para uma nova concepção de autoridade, na qual o príncipe ou o Estado poderiam exercer um poder "não-razoável", mas legalmente: ao indicar a vontade do príncipe como fonte da lei, separando lei e justiça (e, com isso, vontade legisladora e razão), Laurentius oferecia uma perspectiva nova para se pensar o poder. No entanto, mesmo o exercício "não razoável" do poder tinha de ser, em sua argumentação, legal (PENNINGTON, 1991, p. 428).

Outros canonistas o acompanharam, distinguindo a autoridade do príncipe da "moralidade" da lei; mas, ao mesmo tempo, enfatizavam a obrigação do príncipe de se sujeitar à norma por ele estatuída. Dante refletia esta concepção quando fazia do monarca (o imperador, na sua proposta política) um legislador e um servo da lei (ALIGHIERI, 1988, p. 195). Embora os canonistas tenham mantido esta idéia de governo legal (apesar do poder de mudar ou revogar a lei), eles contribuíram de modo significativo, não importa o alcance de sua intenção, para aliviar a noção 
de soberania dos entraves da moralidade, da razão e dos antigos costumes. Este foi um importante passo para o desenvolvimento do pensamento político e constitui um bom exemplo de como se delineava, muito antes de Hobbes, a noção da auctoritas como fonte da lei.

Cumpre ressaltar que os canonistas utilizaram essas idéias para estabelecer os limites constitucionais da autoridade papal, cujo alcance era definido pela noção de plenitudo potestatis, e em pouco tempo seria adotada também para descrever o poder legítimo da monarquia secular. $\mathrm{O}$ próprio papado, em alguns momentos, contribuiu para fortalecer juridicamente as pretensões dos reis ${ }^{11}$. Em 1202, na bula Per venerabilem, o papa Inocêncio III havia declarado que o rei de França não reconhecia superior em questões temporais. Com isso, deixou um problema para os legistas canonistas, que se empenharam em esclarecer o assunto. Segundo alguns, os reis não estariam sujeitos de facto ao imperador, mas sim de iure, enquanto outros afirmavam a completa independência real em relação ao império.

Henrique de Segusio, canonista do final do século XIII, mais conhecido como o Hostiense, tal como Hispanus desenvolveu a noção de plenitudo potestatis, contribuindo também para a melhor definição do conceito de soberania. Também segundo ele, a vontade do príncipe era a fonte da lei; não se limitava pelo rigor da razão e da moralidade e, sob certas circunstâncias, o monarca poderia violar os preceitos de justiça. Dados todos esses pontos, comenta Pennington, estavam presentes os elementos necessários para se pensar o que mais tarde se chamou razão de Estado (PENNINGTON, 1991, p. 433).

Tomás de Aquino, utilizando entre outras fontes os escritos dos canonistas e o direito romano, iria sistematizar uma teoria da lei na qual a íntima conexão entre lei natural e lei positiva iria se expressar ainda mais claramente, de modo que a teoria da lei e a do papel do príncipe se articulariam numa teoria da comunidade política. Com ele, jurisprudência e doutrina do governo se fundiriam e formariam um sistema teórico moldado em princípios aristotélicos. Esses princípios forneciam critérios homogêneos (a noção de finalidade natural e as categorias lógicas, por exemplo) para interpretação tanto dos fatos físicos quanto dos fatos humanos, mas acabaram servindo também à reflexão teológica.

Aquino retomou, a partir de Aristóteles, a concepção do homem como um animal político e social por natureza, isto é, um animal que só 


\section{4}

poderia realizar plenamente suas potencialidades de ser moral e racional na vida coletiva. É parte de sua natureza tender à vida política, assim como é da natureza dos corpos graves mover-se na direção do centro da terra. A condição da excelência humana seria dada pela sociedade política, a mais perfeita das associações, e que engloba todas as demais.

Aquino reconhecia, ao lado da ordem humana, uma ordem sobrenatural, e isso lhe permitia diferenciar o homem natural do cristão, e este do cidadão $^{12}$. Procurando harmonizar as duas ordens, ele recorria à idéia de um Deus criador do natural e do sobrenatural cuja razão regia o universo. A idéia de razão diretora encontrava-se na base da teoria tomista da lei. Segundo ele, era possível falar de lei em quatro sentidos, que se traduziam nos conceitos de lei eterna, lei divina, lei natural e lei humana.

E em que consistiam cada um desses tipos de lei? A lei eterna, primeira e mais universal, consistia na prescrição da razão divina; ela regularia e avaliaria tudo o que está sujeito à Providência e se encontraria impressa em todos os seres. A lei divina, derivada da lei eterna, era formada por aquelas normas que se encontravam nas Sagradas Escrituras, as quais haviam sido oferecidas aos homens pela graça de Deus.

Por lei natural o Aquinate entendia aquelas normas identificáveis, sem referência à Escritura ou outra fonte, por meio da razão humana ou por algo que vagamente poderia se chamar de natureza humana ${ }^{13}$. Era a própria ordem divina e eterna, mas considerada, agora, de outro ponto de vista: o homem podia participar da lei eterna por meio da razão, proporcionalmente à capacidade da sua natureza. A prescrição de Deus podia ser conhecida, portanto, não só como norma revelada, mas por uma inclinação própria da criatura racional.

A lei humana, por sua vez, derivada da lei natural, complementava, em suas diferentes formas, as leis divina, natural e eterna ao ocupar-se dos problemas concretos de uma determinada comunidade; isto é, ela adequava-se a disposições particulares e ajustava-se às diferentes condições de tempo e de lugar. Se a lei natural proibia este ou aquele ato, como o homicídio, por exemplo, à lei humana cabia determinar as circunstâncias segundo as quais esta ação seria avaliada e punida. Outra diferença fundamental se expressava no fato de que a norma fixada pelo homem só podia regular o comportamento observável. Referia-se, portanto, a uma ordem "externa", já que as pessoas não teriam como 
conhecer os estados de espírito das demais. A lei humana, pois, obrigava exteriormente e não no foro de consciência (AQUINO, 1982,Vol. IV, $1^{\text {a }}$ parte da $2^{\text {a }}$ parte, questões 90 e 91, p. 1731-41).

A harmonia entre o sobrenatural e o natural não implicava - e este é um ponto importante - uma subordinação do temporal ao religioso. Assim como os dados do mundo físico, o Estado continha na sua natureza os princípios da sua operação. E isso valia para todos os Estados, tanto os da cristandade quanto os do mundo pagão. Por isso Aquino podia falar de uma virtude do cidadão como de algo específico.

O político em seu pensamento está plenamente constituído como um dado independente, pronto para ser tratado como objeto de ciência. Para Aquino, esta ciência era antes de tudo prática e devia ser entendida como a soma dos conhecimentos necessários ao governo das atividades humanas. Este governo cabia aos príncipes. Aos sacerdotes cabia orar pelo povo e aos soldados, lutar por ele. Segundo o Angélico, era da essência da lei humana ser instituída pelo governante civil e por nenhum outro poder (AQUINO, 1982, Vol. IV, $1^{\text {a }}$ parte da $2^{\mathrm{a}}$ parte, questão 95 da $1^{\mathrm{a}}$ parte da parte II, art. IV, p. 1773).

Regra e medida dos atos, a lei inseria-se, na sua visão, na ordem da razão. Supunha uma razão que guiasse os atos para os seus fins. A vontade que legisla só era válida quando se orientava pela razão. Com isto, Aquino podia definir a lei como uma ordem da razão que visava ao bem comum, estabelecida e promulgada por aquele a quem competia dirigir a comunidade. Primado da razão e rejeição da tirania e do arbítrio de uma vontade, seja ela qual for, caracterizam assim a concepção tomista da lei.

Como se pode notar pela argumentação exposta aqui, a sua teoria da lei já continha os elementos básicos de uma doutrina da soberania e uma teoria da representação. Esta era uma teoria restritiva do poder do governante em face dos súditos. Se o povo "em que se realiza o costume" for "livre e capaz de legislar", escreve São Tomás, "vale mais o consenso de toda a multidão, para o fim de se observar alguma disposição manifestada pelo costume, do que a autoridade do chefe, que não tem o poder de legislar senão enquanto representa a personalidade do povo" (AQUINO, 1982,Vol. IV, $1^{\text {a }}$ parte da $2^{\text {a }}$ parte, , questão 97, p. 1787).

Chevalier chama atenção para um ponto importante: "A Cidade antiga, a polis, a civitas, só pudera se realizar sem chefe único graças às suas 
dimensões restritas e ao vigor do seu ethos próprio. Agora, por volta do fim do século XIII, nas mais ou menos amplas entidades territoriais, os regna, esse objetivo impunha a presença de um rei. Um rei cada vez menos feudal, cada vez menos condicionado em sua ação pelos outros elementos da comunidade (...). Um rei que tenderia cada vez mais ao imperium, à soberania" (CHEVALIER, 1982, p. 222-3). Não há dúvida de que em São Tomás esta é a figura que prevalece quando se trata de apontar as atribuições do governante temporal. O império, em sua argumentação política, já tem pouco espaço e tenderá, daqui para frente, a ser cada vez menos decisivo nos tratados políticos.

A entrada em cena do aristotelismo e a recuperação do direito romano, ao combinar seus efeitos, revelaram-se muito propícios ao desenvolvimento das idéias de soberania e de Estado territorial capitaneado pelo rei. Esses novos elementos foram a base da luta deste poder emergente contra o papado. $\mathrm{O}$ direito romano servira, inicialmente, para reforçar os poderes do império. Pouco mais tarde, no entanto, ao se propagar a antiga máxima do "rex superiorem non recognoscens in regno suo imperator est", os monarcas passaram se beneficiar não só das prerrogativas concedidas ao imperador mas ainda fundamentavam, a partir dela, a sua independência em relação às pretensões imperiais sobre as coroas, além de verem legitimado o seu poder pessoal sobre os súditos.

$\mathrm{O}$ aristotelismo, embora de forma menos explícita, também havia colaborado para a consolidação das pretensões reais, como recorda Chevalier: "Especialmente no que se referia à sociedade política, São Tomás, em vez de considerar o Estado uma instituição meramente convencional, tornada necessária pelo pecado original, lhe havia reconhecido um caráter natural, consentâneo com a natureza moral do homem, e portanto [havia lhe concedido] uma legitimidade ética"14.

Também o separatismo filosófico entre razão e fé comportavam o risco lógico de se manifestar no plano político como uma separação radical entre a esfera do Estado e a da igreja, comenta Chevalier. Essa dupla influência, o direito romano e Aristóteles, poderiam ser percebidos com clareza na querela entre o papa Bonifácio VIII e Felipe, o Belo, rei de França. O Estado franco, na figura de Felipe IV, obteve nessa disputa uma vantagem decisiva e indiscutível, embora tanto o papado quanto o reino tenham produzido argumentos relevantes em defesa de suas posições. E, 
de ambos os lados, a base da argumentação era de origem aristotélicotomista. Aos poucos, a noção de soberania ia se vinculando à de Estado, num movimento de afirmação e avanço contra todos os obstáculos - um caminho que conduziria ao chamado Estado moderno.

Como se procurou mostrar, uma das características relevantes que marcou o pensamento medieval consistiu no fato deste não ter abandonado a velha idéia da supremacia das leis, mas tê-la transformado, por assim dizer, internamente. $\mathrm{O}$ que mudou substancialmente foi o próprio conceito de lei que, de expressão de costumes e usos imemoriais, foi lentamente transformando-se em expressão de uma vontade legisladora consciente e resoluta, suscetível de adaptar-se a situações novas e capaz de lhes fornecer uma regulamentação adequada.

Paralelamente ao desenvolvimento da jurisprudência e da relação entre lei e autoridade, manifestava-se também a preocupação em individuar a sede última do poder e estabelecer sua natureza - condição para uma construção coerente do Estado como ordenamento jurídico. Esta nova realidade do direito acabou se sobrepondo, pouco a pouco, à velha noção universalista e unitária da respublica christiana. Uma determinação rigorosa da sede última do poder e das características próprias ao seu exercício, no entanto, não pôde ocorrer ao pensamento político medieval sem o auxílio do refinamento conceitual operado pelo renovado estudo do direito romano, iniciado na escola de Bolonha e gradualmente difundido por toda a Europa.

Entretanto, mais do que a atribuição do poder a este ou àquele titular, a contribuição mais forte da jurisprudência romana à doutrina política medieval talvez tenha sido a noção romana de populus como fonte originária do poder, que podia se combinar facilmente com a concepção corrente do consenso da comunidade como elemento validante da lei15 - uma idéia cuja tradução pode ser corretamente apontada na famosa máxima de que a norma que se dirige a todos deve ser aprovada por todos ("quod omnes tangit ab omnibus approbetur").

Pode-se sugerir, com Passerin D'Entrèves, sem grandes ressalvas, que tal procura da summa potestas como elemento distintivo e característico das associações políticas não era outra coisa senão a busca daquele atributo fundamental do Estado que um dia será chamado de soberania. Ao imperador, titular único e exclusivo da summa potestas, sucederia não 
somente mas também uma pluralidade de "soberanos". E não se pode negar que, na formação do moderno conceito de soberania, o direito romano desempenhou um papel decisivo.

Como se tentou mostrar, entre 1150 e 1300, legistas, glosadores e filósofos fixaram as principais teorias a respeito da autoridade do príncipe. Alguns deles mantiveram a ênfase na supremacia da lei, eventualmente confundida com a supremacia da comunidade. Outros acentuaram a idéia do príncipe legislador. De modo geral, porém, não se renegava a idéia do governo fundado no bem público. Desses dois modelos seria possível derivar, com alguns acertos, tanto as doutrinas da monarquia absoluta quanto as do governo constitucional.

Num caso, seria preciso acentuar o papel da vontade legisladora e reduzir drasticamente, senão eliminar, a importância de qualquer norma não posta pelo soberano. Em Bodin, houve redução e não eliminação. Ele manteve, por exemplo, referências à lei natural e a uma norma de caráter constitucional, a Lei Sálica (sucessão pela linhagem masculina). Em Hobbes, a concepção do soberano legibus solutus foi radical. No outro caso, os modernos acabariam combinando a idéia da supremacia da lei com a noção de que só poderia haver um soberano, o povo. Locke é paradigma desse tipo de filósofo.

A idéia da lei como expressão de uma vontade soberana, fonte única de validade da norma civil, só se cristalizaria, no entanto, com alguma lentidão. A noção de princeps legibus solutus deve ser entendida de forma variável entre as primeiras grandes discussões, no século XI, e sua tradução radical na obra hobbesiana. Depois de toda argumentação sustentada até aqui, parece plausível descrever esse movimento, de modo muito esquemático, como um percurso entre dois extremos. Num deles, a lei (natural, divina, costumeira, estatuída ou positiva) se sobrepõe totalmente ao príncipe (lex facit regem). No outro, a vontade soberana é fonte criadora, transformadora e revogadora da lei (auctoritas, non veritas, facit legem).

Como todo esquematismo, este deve ser considerado com reserva, porque o voluntarismo já aparece no século XIV e a noção de uma ordem anterior e superior à vontade ainda é visível na literatura política moderna. Mas aquela ressalva (a idéia da evolução) é indispensável. Não anula - ao contrário, acentua - a idéia de um processo formador. Legiti- 
ma, portanto, a pretensão de se falar em Estado e em soberania, na idade média, desde que se saiba que não se trata nem do fato nem do conceito nas formas plenamente amadurecidas.

${ }^{1}$ Doutora pela Universidade de São Paulo e professora de Ciência Política na Universidade Estadual de Londrina, é coordenadora do Grupo Estudos em Teoria Política (GETEPOLCNPq). Este trabalho vincula-se ao projeto de pesquisa intitulado "Direitos humanos, Estado e soberania: alguns problemas teóricos e práticos II", financiado pela Fundação Araucária, e apoiado pela UEL.

2 Segundo Bobbio, a superioridade de fato da lei, mesmo com relação à vontade do príncipe, é um dos princípios fundamentais e constantes da doutrina medieval sobre o Estado. Cf. BOBBIO, 1986, p. 674.

${ }^{3}$ Segundo Chevalier, essa teoria contratual independia, em si mesma, de implicações teocráticas. O rei representava muito mais uma força diretiva do que coercitiva. A supremacia da comunidade e da lei e a teoria contratual impediam, juntas, escreve Chevalier, "o advento da soberania ou poder juridicamente incondicionado de um órgão qualquer do Estado. Na realidade, ninguém é soberano - sobretudo se entendermos a soberania como essencialmente legisladora”. In: CHEVALIER, 1982, p. 211.

${ }^{4}$ Quando Hobbes, por exemplo, discute as formas de governo, ele deixa claro que, do ponto de vista de uma teoria da soberania, não há a menor diferença relevante entre a monarquia, a aristocracia ou a democracia, porque a natureza da soberania é única. Uma soberania exercida de modo democrático não é diferente de uma soberania exercida monárquica ou aristocraticamente. Isto é, o poder não é menos soberano, seja ele exercido por um, por uma assembléia de poucos ou por uma assembléia de muitos. A natureza do poder soberano é sempre a mesma. Pois os atributos do poder soberano - em Hobbes, essencialmente produzir a lei e fazê-la cumprir - são sempre os mesmos. Cf. HOBBES, 1988, p. 239-51.

5 Para este assunto, cf. D'ENTREVES, 1962, p. 139 e seg..

${ }^{6}$ Marcel David afasta sem muita dificuldade a objeção do anacronismo. Depois de examinar o uso das palavras soberano e soberania nos séculos XIII e XIV, ele põe na mesa um argumento muito mais importante: nos séculos XII e XIII, "três das noções expressas em francês pela palavra soberania já existem, simplesmente adaptadas à estrutura da sociedade política do tempo. Duas delas, autoridade suprema e recusa de toda ingerência de um superior no nível de uma potência reconhecida como legítima, se exprimem pela mesma palavra: auctoritas. Quanto à potência pública, é a palavra latina a partir da qual ela se formou, potestas, que habitualmente serve para exprimi-la. Assim, o pensamento político desta época soube fazer do vocabulário um uso mais judicioso do que a partir do século XVI”. In: DAVID, 1954, p. 14.

${ }^{7} \mathrm{Ou}$ seja, a norma consuetudinária, que até um certo momento valeu porque era tradicional e vinha de tempos imemoriais, cederia lugar à noção de que a lei costumeira, embora possa ter tido existência desde o início do mundo, só valeria, a partir de agora, porque o soberano

doispontos, Curitiba, São Carlos, vol. 5, n. 2, p.11-32, outubro, 2008 
decidiu que ela deveria continuar valendo. Mesmo que os seres humanos continuassem agindo exatamente como antes em relação àquilo que era determinado pelas regras costumeiras, a legitimação desse comportamento passava agora a ser dada pela decisão soberana de manter essa norma como tal.

${ }^{8}$ Para o aprofundamento dos interesses e pretensões em conflito bem como dos argumentos conceituais tanto dos defensores do regnum quanto dos do sacerdotium, cf. KRITSCH, 2002, pp. 51-127.

${ }^{9}$ Nos termos de Isidoro: "Ius naturale [est] commune omnium nationum, et quod ubique instinctu naturae, non constitutione aliqua habetur" (L.V, IV). In: ISIDORO, 1989 (1 $1^{\mathrm{a}} \mathrm{ed}$. 1911), s/ p.

${ }^{10}$ Black recorda como os textos do direito romano foram utilizados para atender a múltiplos interesses. A lei romana era "mais específica sobre a extensão dos poderes à disposição de um princeps ou imperator", mas deles se apropriaram os canonistas para expressar a autoridade papal. "Então, os legistas seculares, trabalhando em meios nacionais ou locais, mas empregando a linguagem da lei imperial romana, começaram a aplicá-la, firmemente, a todas as monarquias seculares existentes na Europa, começando pela França e pelo reino da Sicília. Isto acompanhou uma ampla adoção da linguagem imperial por reis e duques, que implicava que os poderes atribuídos ao imperador romano pertenciam propriamente a todo governante vis à vis seus próprios súditos (rex est imperator in regno suo)". In: BLACK, 1992, p. 139.

${ }^{11}$ Para o aprofundamento deste tema, cf. KRITSCH, 2005, pp. 7-26.

12 Para a importância deste assunto no pensamento político medieval, cf. ULLMANN, 1965, p. $180-3$.

13 Esta lei natural consistia em discriminar entre o bem e o mal, fazer o bem e fugir ao mal, não molestar aqueles entre os quais se tem de viver, inclinar-se a uma vida em que se concretiza a natureza racional do homem e que se traduz na vida em sociedade, etc. Cf. CHEVALIER, 1982, p. 217.

${ }^{14} \mathrm{E}$, adiante, Chevalier resume a problemática: “Incitava o espírito a formular questões como a seguinte: se o Estado fosse natural; se ele se explicasse racionalmente e não tivesse qualquer necessidade de uma justificação e sanção naturais; se ele perseguisse um fim não apenas material mas também moral, o de assegurar a seus membros uma vida virtuosa; se ele fosse, em suma, uma sociedade perfeita que se bastasse a si mesma, dotada da autarkeia - por que seria forçado a se submeter à jurisdição moral de um poder exterior a ele, a pretexto de verdade revelada e de vida sobrenatural? o que pode haver de mais irracional?”. CHEVALIER, 1982, p. 227.

15 Passerin D'Entrèves observa que "a escolha entre as duas alternativas, a de individuar no povo ou no príncipe o titular do poder, era no fundo uma escolha política”. Segundo o autor, aliás, a atribuição da summa potestas à comunidade inteira, chefe e membros num único corpo, não foi a contribuição decisiva: mais determinante ainda era a nova concepção do direito como expressão de tal potestas, como instrumento mutável segundo critérios de utilidade contingente, como conjunto de regras que valem e são eficazes. Era a idéia de se colocar o acento sobre a vontade como elemento de coesão das associações políticas que, para ele, iria abrir caminho à grande transformação que estava por vir. Daí a premência de se remontar à 
vontade "que legalmente comanda e não é comandada por outros", de individualizar-lhe a existência concreta. Cf. D’ENTRÈVES, 1962, p. 136 e seg.

\section{Referências bibliográficas}

ALIGHIERI, Dante. 1988. Monarchia. Milano: Biblioteca Universale Rizzoli, Livro I, XII.

AQUINO, São Tomás. 1982. Suma teológica. Porto Alegre: Caxias do

Sul, Escola Superior de Teologia São Lourenço de Brindes/Livraria Sulina Edit./Universidade de Caxias do Sul, Vol. IV.

BLACK, Antony. 1992. Political Thought in Europe 1250-1450,

Cambridge, Cambridge University Press.

BOBBIO, N. et all. 1986. Dicionário de política. Brasília: UnB.

CALASSO, Francesco. 1965. Gli ordenamenti giuridici del rinascimento medievale. Milano: Giuffrè Ed.

CASSIRER, Ernst. 1976. O mito do Estado, Rio de Janeiro: Zahar Editores. CHEVALIER, Jean-Jacques. 1982. História do pensamento político. Tomo I. Rio de Janeiro: Ed. Guanabara.

DAVID, Marcel. 1954. La souveraineté et les limites juridiques du pouvoir monarchique di IXe au XVe siécle, Paris, Dalloz.

D'ENTREVES, Alessandro Passerin. 1962. La dottrina dello Stato.

Torino: G. Giappichelli Ed..

FRIEDRICH, Carl J. 1969. La filosofía del derecho. México: Fondo de Cultura. HOBBES, Thomas. 1988. Leviathan. C. B. MacPherson (Ed.). Harmondsworth: Penguin Books.

ISIDORO. 1989. Etymologiarum sive originum, edição de W. M. Lindsay, Tomo I, Oxford: at the University Press (1 ${ }^{\mathrm{a}}$ ed. 1911).

KRITSCH, R. 2005. "La formulación de la teoría hierocrática del poder y los fundamentos de la soberanía”. In: Res Publica. Murcia: Ed. Universidade de Murcia, v. 1, n. 15. 
KRITSCH, R. 2002. Soberania: a construção de um conceito. São Paulo: Humanitas-Imprensa Oficial.

LUSCOMBE \& EVANS. 1991. "The twefth-century renaissance". In: BURNS, J. H. (ed.). The Cambridge history of medieval political thoughtc.350-c.1450. New York: Cambridge University Press.

PENNINGTON, K. 1991. "Law, legislative authority and theories of government, 1150-1300”. In: BURNS, J. H. (ed.) The Cambridge history of medieval political thought - c.350-c.1450. New York: Cambridge University Press.

ROM., "Epístola aos Romanos”, 2: 12-16. 1995. In: A Bíblia - Tradução Ecumênica. ed. Gabriel C. Galache. São Paulo: Ed. Loyola.

ULLMANN, Walter. 1965. A history of political thought: the middle ages. London: Penguin Books. 